\title{
Peacekeeping in Africa: Reflections on developments and trends
}

\author{
Theo Neethling \\ Centre for Military Studies (Gauteng branch) \\ University of Stellenbosch \\ PRETORIA \\ E-mail: theo@cemis.co.za
}

Abstract

Peacekeeping in Africa: Reflections on developments and trends

Africa is arguably the most important regional setting for United Nations peacekeeping challenges. Hence, Africa is the first continent where extensive efforts have recently been made between the United Nations and the Organisation of African Unity with the specific aim of enhancing the management of conflicts in the region. It is significant that the UN now seems prepared to form partnerships with willing regional organisations and alliances in Africa with regard to the conducting of peace-support operations. At the same time, the United States and certain European nations have begun to support the idea of an African response capability of some kind. Another significant development relates to the fact that sub-regional organisations in Africa have started to feature as important peacekeeping instruments in recent years as it has increasingly been accepted that there is a need for such institutions to take care of their own security requirements. In this regard, the "indigenous" intervention operations without UN endorsement or involvement in Sierra Leone, the Democratic Republic of the Congo and in Lesotho are of particular interest, as these would seem 10 represent a new dimension in the management of African peacekeeping requirements. What is needed in the African context is to establish an acceptable basis for involvement or intervention in intra-state conflicts that respects the dignity and independence of states without sanctioning the misuse of sovereign rights to violate the security of people within a state's borders. It would therefore be desirable that all the roleplayers in Africa and further afield should develop a set of broad principles to respond appropriately and speedily to situations where the security of people is imperilled. 


\section{Introduction}

Africa is a continent that is steeped in conflict and instability, the sources of which are both diverse and endemic. Despair, destitution, poverty, disease, refugee problems and internally displaced people have been among the consequences of such conflicts. In short, there is a pressing need for Africa and role-players in the international community to address and resolve the conflicts on the continent and to lay the foundation for durable peace and economic growth. Without stability there will be little chance for economic development and growth and the marginalisation of Africa in the international community will continue.

It is a truism that the undertaking of peace initiatives in Africa is by no means a simple and easy task. Conflict in Africa poses a major challenge to United Nations (UN) efforts designed to ensure global peace, prosperity and human rights for all. In fact, the African continent has had a critical impact on defining the limits and possibilities of the post-Cold War order and the place of the UN (which has the ultimate responsibility for maintaining peace and security in the world) in this framework. The problems and challenges that the UN has faced in this part of the world have reflected the peculiar difficulties of peacekeeping itself as African conflicts have been among the organisation's most important initiatives in peacekeeping and conflict resolution since the end of the Cold War. In the same sense, recent developments in Africa in the form of frequent conflicts, the tendency of these problems to generate security problems and humanitarian disasters underscore the necessity for leaders on the African continent and other role-players to consider and reconsider response capabilities or regional peacekeeping capabilities of some kind. However, African countries lack the resources and often the political mechanisms to address the conflicts and crises on the continent.

In the light of the above, one of the most important innovations in the management of international security is the concept of shared responsibility between the UN and African stakeholders for the effective management of conflicts in the region. Vogt (1998:1) points out that Africa is the first region where extensive efforts have been made between the UN and the Organisation of African Unity (OAU) specifically to enhance the management of conflicts in the region.

In the following analysis, an overview is given of the management and conducting of multinational peace-support operations. The international peacekeeping system as well as the general framework for security co-operation and related developments in Africa are especially assessed. By the same token, an attempt is made to reflect upon the trends and direction of peacekeeping efforts in the African context with special reference to recent developments. 


\section{Conducting multinational peace-support operations}

Success in any peace-support operation depends upon a broad political process. Such missions never comprise military exercises only. In fact, military operations play a distinctly supportive role, and may even produce few obvious results as regards the outcome. Hence, peace-support operations are critically dependent on the extent to which international authority underpins such operations and on the political will of participating member states. This kind of authority is necessary to assist in reducing political pressure on the countries responsible, to avoid international isolation of the participating countries if the operation "goes wrong" and to prevent overextending the capabilities of any country's armed forces (Williams, 1995:91-92). Of significant importance is the role of the UN as regards the broad political apparatus or institutional framework created to manage co-operative security and to co-ordinate peace missions.

The 15 member states of the Security Council - not the Secretary-General create and define peace-support operations. The UN Charter specifies that the Council has primary responsibility for the maintenance of international peace and security (United Nations, 1998b). The first of the objectives of the UN listed in its Charter is

[t]o maintain international peace and security, and to this end: to take effective collective measures for the prevention and removal of threats to the peace, and for the suppression of acts of aggression or other breaches of the peace, and to bring about by peaceful means, and in conformity with the principles of justice and international law, adjustment or settlement of international disputes or situations which might lead to a breach of the peace (United Nations, 1945).

Concrete measures that are to be taken by the UN Security Council are set out in Chapters Vi and VII of the Charter. Chapter VI provides that international disputes "likely to endanger the maintenance of international peace and security" can be brought to the attention of the Security Council or the General Assembly. If the Security Council determines that a threat to the peace, breach of the peace or act of aggression exists, the Council may use the broad powers given to it in Chapter VII of the Charter. Should the Security Council regard it necessary, it may take, under Article 42, "action by air, sea and land forces as may be necessary to maintain or restore international peace and security" (United Nations, 1945).

As already mentioned, the end of the Cold War has not reduced threats to peace and has in fact seen the transformation (or mutation) of classical peacekeeping operations into multidimensional conflict management activities. Accordingly, the UN requested Boutros Boutros-Ghali, then its Secretary-General, to prepare a report containing “... an analysis and recommendations on ways of strengthening and making more efficient within the framework and provisions of 
the Charter the capacity of the United Nations for preventive diplomacy, for peacemaking and for peacekeeping". As a result, his report, An Agenda for Peace was submitted in 1992 and has since served as a broad framework for peace-support operations (Boutros-Ghali, 1992:1).

Because the $\mathrm{UN}$ is the source of authority for types of peace-support operations, its set of terms and definitions is of importance. An Agenda for Peace has sought to identify a new approach to UN peacekeeping. It suggested that it was no longer appropriate to consider peacekeeping in isolation, and presented the concepts of preventive diplomacy, peacemaking, peacekeeping and post-conflict peacebuilding as a range of options to be considered in the context of peacesupport activities. None of these concepts were really new, but in this case they were presented together for the first time. In his report, the terms 'preventive diplomacy', 'peacemaking', 'peacekeeping' and 'post conflict peacebuilding' were defined as follows

- Preventive diplomacy is action to prevent disputes from arising between parties, to prevent existing disputes from escalating into conflicts and to limit the spread of the latter when they occur.

- Peacemaking is action to bring hostile parties to agreement, essentially through such peaceful means as those foreseen in Chapter VI of the Charter of the UN

- Peacekeeping is the development of a UN presence in the field, hitherto with the consent of all parties concerned, normally involving UN military and/or police personnel and frequently civilians as well. It is a technique that expands the possibilities for both the prevention of conflict and the making of peace.

- Post-conflict peacebuilding is action to identify and support structures, which will tend to strengthen and solidify peace in order to avoid a relapse into conflict (Boutros-Ghali, 1992:11)

It is noteworthy that 'peacemaking' refers to the use of diplomatic means to persuade parties in conflict to cease hostilities and to negotiate a peaceful settlement of their dispute. As with 'preventive diplomacy', or 'preventive action', as it is currently referred to by the Secretary-General of the UN, the UN can play a meaningful role only if the parties to the dispute agree that it should do so. Peacemaking thus excludes the use of force against one of the parties to enforce an end to hostilities, an activity that in UN parlance is referred to as 'peace enforcement' (United Nations, 1998a:1). Over and above, the notion 'peace-support operations' is now widely used in doctrine, for example, in documents of the North Atlantic Treaty Organisation (NATO), to cover all 'peacekeeping', 'peace enforcement' and related operations. 
Another significant development of the 1990 s relates to the fact that cooperation between the UN and regional organisations has greatly increased in the 1990s. Yet, the concept of co-operation is not entirely new. The UN Charter provides for the involvement of "regional arrangements or agencies" for maintaining international peace and security along with the UN since 1945. Article 53 of the UN Charter even refers to enforcement action by regional bodies under UN authority (United Nations, 1945:11).

It is commonly known that the UN is over-extended in terms of resources and capacity to perform effectively the many peace-support tasks it has assumed over the last decade. Having reached a critical point, this has called for an appropriate division of responsibilities between the UN and other role-players in the sphere of peace-support operations. In Africa, prospects to manage conflict by means of peace-support operations are closely linked to the dynamics of regional and sub-regional peace initiatives.

\section{Regional peace initiatives}

Conflict resolution and the issues of peace, security and stability have been major concerns of the OAU since its inception in 1963, when it was confronted with three categories of peace and security:

- disputes involving only its members;

- situations involving members with colonial regimes; and

- situations resulting from relations between members and states outside Africa.

The first category involves territorial and other disputes between member states Internal disputes have been outside the sphere of the OAU or the UN until as recently as 1993, except when there were international implications. To this end, the OAU has been involved in finding solutions to the conflicts in Chad and Nigeria. Both the OAU and the UN have been involved in the second category, for example in Namibia. In such cases there has been great reliance on the UN. The third category relates to experiences where there were large-scale outside interference, such as in the Congo in 1960-64 and Nigeria in 1967-70.

Over and above, ad hoc arrangements were in effect the order of the day in OAU dealings with inter-state conflicts, while intra-state conflicts were largely left to each member state to handle (Nhara, 1995:103). Another relevant factor in this context relates to certain core principles of the OAU, which member states pledged to 'observe scrupulously'. They are:

- the sovereign equality of all states;

- non-interference in the internal affairs of states; and 
Peacekeeping in Africa: Reflectlons on developments and trends

- respect for the sovereignty and territorial integrity of each state and its inalienable right to independent existence.

These provisions mean that unless the government of the state in question decides to ask for international support for conciliation in inter-state or intrastate conflicts, or the UN Security Council decides that intervention is required there are no coercive instruments to address any incipient crises. In addition to ad hoc arrangements, these provisions have constantly posed particular difficulties in conflict management and resolution in African states wrecked by civil war or other forms of violent dissent (Steyn, 1997:9).

In 1991, the OAU committed itself to deploying greater efforts towards the creation of an enabling environment for conflict prevention, management and resolution (Organisation of African Unity, undated). The Kampala Document of 23 May 1991 represented the first concerted African call for a continental peacekeeping body in Africa. Although not an official OAU document, it nevertheless carried considerable weight

In the Kampala Document it was suggested that Africa should institute a continental peacekeeping machinery as an important instrument for the preservation of peace in instances which potentially or actually threaten the security of African state(s) or the continent as a whole. In order to realise the establishment of a continental peacekeeping body, each participating member state was called upon to implement special training measures in peace-support operations for a contingent of its armed forces. In view of this, a continental peace-support operation was regarded as an ad hoc operation through rapid mobilisation of pre-agreed manpower and financial contributions from member states (Anon., 1991:iv-v).

Another important milestone was the establishment of the OAU's Mechanism for Conflict Prevention, Management and Resolution in Cairo in 1993. This was a less ambitious initiative and should be seen as a departure from the OAU's earlier ad hoc arrangements for conflict management. It confirmed African leaders' determination to work together and assume greater responsibility for the maintenance of peace, security and stability on the continent

In establishing the Mechanism, the African heads of state and government were inter alia guided by the following principal considerations:

- The UN should clearly remain the pre-eminent international authority with the responsibility for dealing with international peace and security, including internal crises, which threaten regional stability in Africa.

- The UN, together with regional and sub-regional organisations should form a partnership in framing new approaches to crisis prevention, management and resolution in the post-Cold War era. 
- Regional and sub-regional organisations on the one hand, and the UN system on the other, should endeavour to share proportionately the burden relating to the maintenance of worldwide peace, security and stability.

- As a regional organisation, the OAU should realise the need for it to take primary responsibility for its own problems, especially those relating to issues of peace, security and stability (Nhara, 1998:33-34).

It was declared that the primary objective of the Mechanism was the anticipation and prevention of conflicts. In circumstances where conflicts have occurred, it would be its responsibility to undertake peacemaking and peacebuilding functions in order to facilitate the resolution of such conflicts (Organisation of African Unity, 1993). The OAU has, accordingly, spent a lot of energy in assuring that the Mechanism becomes fully operational (Nhara, 1995:104). Yet, it cannot be stated that the Mechanism has made a significant impact since it was created in 1993 (Berman \& Sams, 1998:6)

As far as funding of support operations on the African continent is concerned, it must be noted that a special fund, known as the 'OAU Peace Fund', was created in the wake of the adoption of the OAU Mechanism for Conflict Prevention, Management and Resolution. The purpose of this fund is to provide exclusive support for OAU operational activities relating to conflict management. Contributions to this fund will be used for OAU activities undertaken within the framework of conflict anticipation and prevention, peacemaking, peacebuilding and peacekeeping (Nhara, 1995:107).

In conclusion, it is stipulated in the UN Charter that regional problems should, ipso facto, have regional solutions. Hence, there is a pressing need for regional organisations, such as the OAU, to take care of their own security problems and the burden of conflict. In addition, it is today believed that sub-regional organisations should also endeavour to share the burden relating to the maintenance of worldwide peace and security proportionately.

\section{Sub-regional peace initiatives}

The OAU was entrusted with the responsibility of promoting the unity and solidarity of African states and ensuring the peaceful settlement of disputes by negotiation, mediation, conciliation or arbitration, and has had this responsibility for peacekeeping since its inception in 1963. The first real peacekeeping test for the OAU was the Chadian imbroglio which was dealt with in 1981 by the OAU heads of state and since then, the OAU has dealt with many and varied forms of conflict (Olonisakin, 1997:351; Nhara, 1995:101-102). However, the OAU, as the UN at the top of the pyramid, is experiencing financial problems. From this account, a tenuous financial base hampers the OAU's ability to make progress in promoting peace and security (Berman \& Sams, 1998:6). 
In the light thereof, it would seem that a devolution of responsibility from the UN to regional or sub-regional organisations, such as the Southern African Development Community (SADC), offers the benefit of alleviating capacity problems for the cash-strapped UN by assuming or sharing some of its peacesupport responsibilities. The assumption is furthermore that because such organisations are more familiar with the local conditions, they have a comparative advantage to play a conflict-resolution role in volatile parts of the world (Vogt, 1998:8)

If regional organisations are primarily responsible for dealing with their own security problems, it does not imply that this step diverts from UN guidance and control. Regional organisations and arrangements on the one hand, and the UN system on the other, should endeavour to share the responsibility of maintaining peace. According to Nhara (1995:100) the UN and regional and sub-regional organisations should form and maintain partnerships and act decisively and expeditiously when framing new approaches to crisis prevention, management and resolution. However, the UN, with its cumulative experience, should remain the pre-eminent international authority responsible for dealing with international peace and security, as well as with internal crises that threaten regional stability, particularly in sub-Saharan Africa. On this account, Arnold (1997:33) concludes that it relates to an approach that assigns peacekeeping responsibilities to regional or other organisations in accordance with current UN policy.

At sub-regional level the most prominent organisation in Africa involved in peace initiatives thus far is notably the one created for the Liberian conflict by the Economic Community of West African States (ECOWAS). Initially termed a "Monitoring Group", this military organisation is generally known by its acronym, ECOMOG. It developed in August 1990 out of the military forces deployed into Liberia in an attempt to put an end to the civil war. Over the period of its existence, it has included contingents from eight West African and two East African States.

ECOMOG has since its exception been controlled largely by Nigeria. Critics of the organisation have often complained that the organisation was a thin veil for Nigerian hegemonic ambitions. This generally accompanied accusations that Nigerians controlled all the key staff positions and unfairly diverted resources to their fellow countrymen. It also included allegations of Nigeria's lack of neutrality, which has led to a severe degradation of ECOMOG's credibility as a role-player in the Liberian conflict (Henk, 1995:13). In 1997 ECOMOG made international headlines when it intervened in Sierra Leone to reverse a military coup and restore power to elected President Ahmad Tejan Kabbah. Again Nigerian domination was prominent as hundreds of Nigerian troops were sent in with a view to driving out the military regime (Anon., 1998c:7). 
Another significant example of developing responses to African crises in West Africa relates to the two-year-old conflict in the Central African Republic in the form of the Inter-African Mission to Monitor the Bungui Accords (MISAB). Provided with a UN mandate, MISAB formally became the buffer between the combatants on 12 February 1997. Comprising just over 1000 soldiers from six African countries, the force was commanded by a Senegalese officer and supported by French logistics. Although small in size and posture, and perhaps insignificant in world politics, MISAB has reduced the tensions and security problems in the Central African Republic in its attempt at indigenous multinational peacekeeping. MISAB has proved that there is a political will towards contributing to peaceful conflict resolution in certain parts of Africa (McFarlane \& Malan, 1998:48, 53, 57).

A further meaningful development in West Africa relates to a military exercise held in Senegal in March 1998 which featured a mock operation to protect civilians in war zones, fly them to safety and organise refugee camps. Senegal, Mauritania and Mali organised and commanded the exercise in which soldiers from Guinea, Guinea Bissau, Ghana, Gambia and Cape Verde took part. France supplied the equipment and was responsible for the logistics while the US and Britain sent troops. The exercise also enjoyed the support of the SecretaryGeneral of the UN and can clearly be regarded as part of capacity-building efforts to establish a regional or sub-regional response capability of some kind (Gibson, 1998:11).

In Southern Africa the initiatives of SADC represent an important step in the development of regional solutions to regional problems. As far as peace-support operations are concerned, SADC's Organ for Politics, Defence and Security at political level and the Inter-State Defence and Security Committee (ISDSC) at technical level will seemingly provide the possible future framework for cooperation and assistance for such operations, as well as co-operative security in Southern Africa.

The objectives of the SADC Organ for Politics, Defence and Security place a heavy emphasis on the development of political and diplomatic skills to deal with the prevention and resolution of intra- and extra-regional conflict; a commitment to a common regional (Southern African) approach to all issues and problems of mutual concern; and undertakings to foster democratic institutions and practices within member states. Of particular concern is the objective to develop a collective security capacity; to conclude a Mutual Defence Pact for responding to external threats; and to develop a peacekeeping capacity within national armies that could be called upon within Southern Africa or elsewhere on the continent (Van Aardt, 1997:7-18).

An approach to what appears to be a possible (and perhaps ideal) future model for peace-support operations in Southern Africa is the following: Firstly, that 
such operations will be undertaken by $\mathrm{SADC}$ as a sub-regional organisation Secondly, that such efforts be politically and morally fully sanctioned and supported by the OAU, while the UN will provide the necessary international support and endorsement.

However, the progress made in 1996 with the establishment of the SADC Organ on Politics, Defence and Security has come under pressure as problems are being experienced in respect of the actual realisation of objectives and the structuring of the various institutions of the Organ. There is still a need for proper structural arrangements and divergent positions on its operational procedures (Tsie, 1998:8). The main problem evidently relates to differences between the heads of state - especially between South Africa and Zimbabwe over the political control and status of the Organ. Some SADC countries, including South Africa, believe the body should fall under the SADC chairperson, while others, including Zimbabwe, maintain that it should be an autonomous body (Fabricius, 1998a:6). Much will therefore depend on efforts to resolve this problem and the measure of future political cohesion in SADC.

On the positive side it should be mentioned that the ISDSC successfully managed to initiate discussions on security co-operation since 1995. As a result, the armed forces of the majority of Southern African countries (including a contingent of the South African National Defence Force) participated in Exercise Blue Hungwe (Fish Eagle), a multinational peace-support exercise held early in 1997 in Zimbabwe, assisted and facilitated by British military experts. Exercise Blue Hungwe was followed by Exercise Blue Crane held in April 1999 in South Africa at the grounds of the SA Army Battle School in the Northern Cape Province (Southern African Development Community, 1999:5-6) and was clearly the biggest peacekeeping exercise of its kind ever conducted on African soil. With these exercises the subregion came closer to sharing peace-support responsibilities on the African continent.

\section{Externally inspired capacity-building efforts}

As a result of the need to intervene in internal crises, the United States (US) and some European nations, especially France and Britain, have started to support the idea of an African response capability of some kind, staffed and commanded almost exclusively by Africans. In this context, the African Crisis Response Force and the African Crisis Response Initiative (ACRI) have successively been tabled as the American answers to Africa's peacekeeping challenges. The former was introduced in 1996 and related to the institution of a standing African force tasked with a peacekeeping responsibility, but was not met with a great deal of enthusiasm within Africa and elsewhere (Williams, 1997:1). The latter was a reaction to the lukewarm African response and can be regarded as a long-term plan; a first step in a programme to encourage and assist African countries in 
training and capacity building to develop or establish a response capability of some kind (Whitelaw, 1997:36).

While the ACRI is mainly aimed at capacity building through training, it is hoped that the initiative will eventually be instrumental in promoting peace on the African continent. As far as deployment is concerned, the political authority would come from the UN Security Council and not from the ACRI itself. Accordingly, once trained, it is envisaged that participating units would be deployed, when called upon to do so, as part of

- a UN operation, under the political direction of the UN;

- a multinational force with Security Council approval, but where a group of countries have come together on a voluntary basis to provide the peacekeepers (perhaps with an African country assuming the leading role);

- a force constituted by member states and directed by a sub-regional organisation; and

- an operation undertaken by the OAU (Malan, 1997:1)

Even if the ACRI has come a long way since it was proposed as the ACRF, a host of issues have been brought up in criticism against the US initiative. Firstly, there is a perception that an approach to develop an indigenous African capacity to deal with conflicts on the continent represents a trend towards a "do-ityourself project' of peacekeeping in Africa; of removing African problems from the UN agenda. It is thus an issue of Western nations trying to give themselves an excuse not to become involved in African conflicts (Whitelaw, 1997:35).

A further bone of contention relates to the fact that the ACRI is perceived in some circles to be a unilaterally US driven initiative, despite assurances to the contrary (Malan, 1997:4). On the positive side the idea of an all-African Military Peace Force trades on the growing sentiment among many African armed forces (particularly those with peacekeeping experience) that they are not afforded the necessary seniority and responsibility in the conduct of peace missions particularly on African soil (Williams, 1997:1). At the same time the ACRI is based on the premise that if the international community has a capacity or group of military units in Africa from which it could draw a peacekeeping force, it would be better prepared to respond to conflicts and crises in Africa (Jamerson, 1998:43). There is, furthermore, little doubt that the ACRI is a result of the all but outstanding performance of the UN system in the field of African peacekeeping and that UN peacekeeping is clearly in a poor state in terms of finances, doctrine, troop contributions and co-ordination. A number of missions, especially Rwanda and Somalia, have served to underscore the problems of the UN in this regard (Malan, 1997:5) 
However, the US is still faced with several challenges. The first is to persuade African governments to sign up. Only a limited number of African states have accepted the American concept of military training and capacity building, namely Uganda, Senegal, Malawi, Ghana and Mali (Berman \& Sams, 1998:15) Some of Africa's armies are still on the sideline, watching others to oversee the peacekeeping requirements. The lack of a clear concept for capacity utilisation under $\mathrm{UN}$ and $\mathrm{OAU}$ auspices might also have caused reservations agains signing up. Nigeria, unquestionably the giant in West Africa, could not participate until recently because of US sanctions against the country's political leadership ${ }^{1}$. South Africa, the political leader in Southern Africa and perhaps the strongest military force on the continent, has not explicitly committed itself to participation in the ACRI (Whitelaw, 1997:36), although it has come to support the principle of strengthening Africa's capability at peacekeeping.

By design, the ACRI is now regarded as a long-term plan; a first step in a longterm programme to encourage and assist in the transformation of the African security environment where most violence that does occur can be handled without massive outside involvement or unrealistic demands on American resources (Henk \& Metz, 1997:ix, xi). By the same token, there is already a good foundation in Africa to build on as regards future peacekeeping requirements. The OAU has gained experience in monitoring problem areas. A number of African states have been participating in peace-support operations under UN mandates. Many African states have troops prepared to participate in peacekeeping operations, but not the resources to finance them. In addition, several members of the international community are willing to support peace missions in Africa, but believe that African nations should take the leading role (Institute for Public Policy, 1998).

Some observers correctly point out that the OAU, unlike the UN, was not created for the purpose of maintaining peace and security and that most regional organisations currently lack the capacity to direct and control a peace mission (Malan, 1997:6). On that score, what the US envisages is to provide capabilities and resources to support the existing capacity that Africans have demonstrated in the area of peacekeeping and to create a capacity to respond more quickly to crisis situations on the continent, whether it be involvement in conflict situations, humanitarian assistance, or response to natural disasters (Institute for Public Policy, 1998). Moreover, the concept of the ACRJ seems to fit into a stronger role for sub-regional organisations, as it provides for forces constituted by African states and directed by a sub-regional organisation with Security Council approval (Shelton, 1987:82). Quite appropriately, the US has now come to recognise the growing role of sub-regional organisations and their initiatives 
to promote the development of a peacekeeping capacity to respond to emergency situations in Africa (Jamerson, 1998:44).

In general, what seems to be lacking thus far is the aspect of meaningful cooperation. Without such co-operation, it will be impossible to establish a clear direction and guidelines as to the nature and scope of interventions for which African personnel and capabilities will most likely be required and under whose direction deployment will take place. What is likewise needed, is what may be described as the 'command and control'-element, or clarity on the higher headquarters that can direct and sustain efforts to bring Africans from several different nations together to train and achieve a common purpose on the continent (Jamerson, 1998:46). It can furthermore be stated that, for the US to succeed in shaping the African security environment, it will have to develop a pattern of regional engagement based on consultation, consensus and cooperation. Only in this way will they provide some benefits to Africans and be able to support US ideals and interests in Africa.

In the light of previous debates on the issue and as a result of the abovementioned initiatives, the OAU Council of Ministers has decided in February 1998 to accept the principle of an African peace force of some kind that will carry out peace-support operations under UN and OAU auspices. They have also acknowledged the efforts and initiatives of the US, France and Britain to improve the ability of African forces to conduct peace-support operations in Africa (Anon., 1998b:9). However, many questions remain unclear, especially as regards the following:

- What will the generic objectives governing African involvement in peacesupport operations be?

- In what kind of peace-support operations will such a force be prepared to engage?

- How will the financial arrangements for peace-support operations be determined?

- How will African entry and exit criteria be determined and who should be the key role-players in setting the necessary parameters?

- What should be done in the fields of interoperability of equipment; formulation of common doctrines; allocation of responsibilities to different participating states; command responsibilities within combined forces, and many more? (Williams, 1997:3).

Over and above these questions, an integrated African and sub-regional policy on peace-support operations seems to be imperative. At the same time, it should be borne in mind that peace-support operations are international endeavours, endorsed by the $\mathrm{UN}$, and conducted in accordance with the internationalist ethos 
of the UN Charter (Williams, 1997:2-3). Against this background Vogt (1998: 12) argues that the ideal arrangement will be one in which the OAU is fully involved in all aspects of the preparations of African forces for UN operations on the continent. The OAU should, furthermore, be in a position to deploy peace missions into African conflicts, based on a UN mandate and with sufficient political and financial backing from the international community.

\section{Continued UN involvement in African peacekeeping}

African countries have begun to make economic and political progress in recent years, but in some parts of the continent progress remains threatened or impeded by conflict. The question is: Where is African peacekeeping heading in the future? If the report of Kofi Annan, Secretary-General of the UN, on The Causes of Conflict and the Promotion of Durable Peace and Sustainable Development in Africa is to be taken as a pointer towards the future of $\mathrm{UN}$ involvement in African peacekeeping requirements, it would seem that the organisation is eager to add momentum to Africa's renewed quest for peace and greater prosperity. Three aspects are of special relevance:

- The Secretary-General holds the view that under the right conditions, UN peace-support operations can make the difference between peace and war in Africa. However, his view includes the realisation that UN peacekeeping will not always be the best answer to every problem in Africa or elsewhere. Yet, where opportunities in Africa arise, the international community should provide its support, demonstrating its commitment to peace in a tangible way

- Most important is the Secretary-General's view that the provision of support for regional and sub-regional initiatives is regarded as both necessary and desirable. It is necessary because the UN lacks the capacity, resources and expertise to address all problems that may arise in Africa. It is also desirable because, wherever possible, the international community should strive to complement rather than supplant African efforts to resolve Africa's problems. By the same token, reinforcing the capacity of African countries to operate in peace-support operations is a key priority, whether those operations take place in the framework of a UN mission or are conducted by a regional organisation or group of states in accordance with Security Council authority. The Secretary-General recognises that, in recent years, there have been a number of new African initiatives to resolve disputes that have long plagued particular areas or to tackle new conflicts before they can expand and escalate beyond control. The activities of ECOMOG in Liberia are especially regarded as an example of co-operation between the UN and a sub-regional organisation that might be applicable to future situations.

- The view is also held that wide disparities in the international community's commitment to preventing or containing conflicts in different regions impede 
the ability of the UN to promote a stable and just international order anywhere. Member states must therefore be engaged in terms of political will and practical resources if the viability of the UN and the principle for which it stands are to be safeguarded, let alone advanced (Annan, 1998b).

In addition, summoning the necessary political will is at stake. According to Annan, this relates to two aspects:

- Firstly, that Africa must demonstrate the will to rely upon political rather than military responses to problems. African countries must likewise summon the will to take good governance seriously, ensuring human rights and the rule of law, strengthening democratisation and promoting transparency in public administration.

- Secondly, political will is also needed from the international community. Where the international community is committed to making a difference, it has proved that significant and rapid transformation can be achieved (Annan, 1998b)

Against this background, it is realised on the part of the UN that the credibility of the world body in Africa depends to a great extent upon the international community's willingness to act and to explore new means of advancing the objectives of peace and security on the continent (Annan, 1998b). Therefore, since the current Secretary-General of the UN assumed office in 1996, the OAU and African governments have been engaged in discussions on the ways and means by which the UN and the OAU can collaborate better to prevent, manage and resolve conflicts in the African environment more effectively (Vogt, 1998:11).

What is also significant in view of the above is the fact that the UN now seems prepared to form partnerships with willing regional organisations and alliances in Africa. In the case of the Liberian peacekeeping effort (which is especially regarded as an example of co-operation between the UN and a sub-regional organisation) the more robust 'peacekeeping' was done by ECOMOG, while the UN mission was deployed to observe the 'peacekeepers' as well as the belligerents (Malan, 1998a:4). What is of concern are ways and means through which the UN can operate in closer co-operation with African stakeholders.

\section{Non-UN intervention operations}

The past decade has recorded a growth in intervention operations internationally, under the guise of peacekeeping or peace enforcement, usually under the auspices of the UN. At the same time, it would seem that the UN is a cumbersome participant in the attempted settlement of Africa's fluid and complex conflicts. It is hampered by peculiar decision-making mechanisms and 
chronically short of cash as recalcitrant members states refuse to pay their dues. In addition, it has to look constantly over its shoulder to the demands of the major powers and is characteristically under pressure to look for cheap and quick fix solutions to conflicts (Clapman, 1998:3). It has also become apparent that the UN can only be mobilised effectively to intervene in a crisis when the interests of the major powers, especially the Security Council members are effected. To this end, the intervention of ECOWAS in Sierra Leone and SADC member state's military intervention in the Democratic Republic of the Congo (DRC) and in Lesotho without UN endorsement and involvement is of particular interest.

On 25 May 1997, the rule of President Ahmed Kabbah was overthrown by Major Johnny Paul Koroma; the third change of government by force in five years in Sierra Leone. The coup was the most bloody and destructive in Sierra Leone's history as nationalist appeals helped win over the Sierra Leone Army. The justifications of the coup were very self-serving, as Koroma's first public statement on 28 May made mention of intervention because the country had "polarised into regional and tribal factions" and the peace agreement in the country had collapsed. The coup derailed a brief democratic exercise: Kabbah's multi-party civilian government lasted just more than a year after elections in February 1996

The OAU, Commonwealth, ECOWAS and Western governments condemned the coup. Ghana's President, Jerry Rawlings, and Nigerian Foreign Minister, Tom Ikimi, initially tried to negotiate with the rebels by telephone. But ousted President Kabbah requested Nigeria to intervene whereafter the Nigerian forces rushed to Freetown in an attempt to unseat the new military regime. The OAU and Commonwealth then implicitly blessed the intervention, but the fact remains that Nigeria went to Sierra Leone under the banner of ECOMOG without any official mandate (Anon., 1997:7). The intervention was a direct result of a defence agreement between Nigeria and the government of Sierra Leone which provided for military and security assistance for sustenance of the sovereignty and territorial integrity of the latter (Hough, 1998:35).

The political crisis in Sierra Leone eventually erupted into a full-scale war, with West African forces backed by warplanes and heavy artillery battling to evict the country's new unrecognised military rulers. In February 1998, Nigerian troops managed to record a measure of success in their efforts to oust Sierra Leone's military junta from the capital, Freetown. However, the largely Nigerian intervention force came under increasing criticism, especially since Nigeria itself was ruled by a military junta (Sapa-AFP \& Reuters, 1998:4). By 15 February 1998, virtually all Freetown had been taken by a pincer movement of the wholly Nigerian force (Anon., 1998b:7) and ECOMOG was commended by the Secretary General of the OAU for its initiative (Gibson, 1998:9). At the same time, many people got killed and thousands fled as shells hit residential areas, 
despite repeated pleas to combatants not to fire blindly, or target civilians or to use them for any military purpose (Sapa-AFP \& Reuters, 1998:4). Yet, peace has not been restored in this conflict-ridden country.

In August 1998, SADC became the focus of international attention when Angola, Zimbabwe and Namibia decided to take part in an intervention operation in the DRC. The decision was based on requests from President Laurent Kabila for military assistance (DRC became a member of SADC in 1997) against advancing rebel forces. South Africa specifically stressed the need for a peaceful solution and declined to send troops. It was also reported that South Africa would only consider sending troops should a peacekeeping force (presumably in accordance with a UN mandate) be deployed in the DRC. This resulted in criticism from Zimbabwean President, Robert Mugabe, as the leading figure in the mission to prop up the regime of Kabila, who got to power through military force - but who was referred to as "legitimate" by President Sam Nujoma from Namibia.

The South African decision eventually proved to be a wise one as Rwanda and Uganda decided to engage in the conflict in support of the rebel movement, while Chad and Sudan were subsequently drawn in to fight on the side of Kabila (Lötter, 1998:9). Another important point relates to the fact that Zimbabwe and Angola got criticised as reporters claimed that Zimbabwe's main motive was an effort to push Zimbabwean business into the Congo. Similarly, it was reported that Angola's interest was to prevent the Angolan rebel force, Unita, from using the DRC as a rear-base (Fabricius, 1998b:8).

In September 1998, shortly after Kabila's request for assistance, South Africa and Botswana intervened in Lesotho in an attempt to stop a possible coup from the Lesotho armed forces. The decision was based and justified by referring to the fact that SADC was directly approached for intervention by the Prime Minister of Lesotho, Pakalitha Mosisili, that the intervention was based on agreements reached in $\mathrm{SADC}$; and that all attempts at peaceful resolving the dispute had failed. It was furthermore stated that the Lesotho government was democratically elected (despite certain irregularities during the election process) and that it was increasingly required of South Africa to play a role in regional peacekeeping efforts (Hough, 1998:38). In addition, it was stated that the decision gave notice to ambitious elements in the military forces in the region that in no member state would the political aspirations of any military faction be tolerated, and that South Africa's commitment to this policy was a commitment to development in the region (Haysom, 1998:6).

Several questions were raised in the light of the above-mentioned. For example, as far as legitimacy is concerned, Hough (1998:37) rightfully poses the question whether ex-President Mobutu Sese Seko's position in the former Zaire would have been different had the country been a member of SADC at the time of the 
Peacekeeping in Africa: Reflections on developments and trends

rebellion in 1997 when he was toppled by Kabila. Some relevant questions are accordingly:

- When is a leader legitimate, or is legitimacy something in the eye of the beholder?

- Should there be UN Security Council permission for intervention in such cases?

- What about future responses to internal conflicts in terms of SADC objectives?

Suffice it to say that these questions mainly dealt with the modus operandi of the intervention, and not the principle. However, these would seem to be important issues and they need to be addressed at multinational level.

Finally, it should be borne in mind that the costs of the above-mentioned "SADC operations" in the DRC and Lesotho had to be borne by the relevant countries themselves. In fact, it proved to be relatively huge and drained the resources of the respective countries. In the case of the Zimbabwean and Angolan participation in the DRC it was reported that these countries have indicated that they were not able to sustain their involvement for a long period (Mdhlela, 1998:1). In Zimbabwe, for example, a tone bordering on panic started to pervade Zimbabwe's business community a few weeks after the intervention, where each day was greeted with outrage at the plummeting local dollar (Anon., 1998a:4). The intervention operation in Lesotho has similarly been the cause of a serious discourse in certain circles as regards the ability and capabilities of Southern African forces to engage in peacekeeping incursions. Overall, the question is whether regional or sub-regional institutions in Africa are ready and geared to engage in peacekeeping efforts on their own and even whether they should opt for such a route in future.

\section{Whither Non-UN intervention operations}

Bir (1997:22) states that the internal affairs of many countries have become an important component of the new world order, making intervention a legitimate right. It can even be regarded as an obligation upon the international community whenever a risk or threat to international peace arises. This implies that the broad community of nations has the legitimate right and responsibility to intervene when conditions require people to preserve peace.

The question is: Given the sustained importance of the principles of sovereignty and non-interference in internal affairs, when should a situation in an African state be considered to have deteriorated to such an extent that the security of people has been violated to the point that it requires international and/or regional response on humanitarian grounds? 
Until recently, intervention operations have been conducted under the auspices of the UN and under the guise of peacekeeping and especially peace enforcement. The UN operations in Somalia is a typical example in this regard as it was basically a peace-making operation based on Chapter VII of the UN Charter (Bir, 1997:24). However, it has been indicated in the preceding that recent developments in Africa (Sierra Leone, the DRC and Lesotho) have all pointed towards intervention operations without UN endorsement.

In this context, it should be noted that the formulation of UN mandates is generally a time-consuming process that does not in principle provide for swift intervention in internal crises. For example, in the conflicts in Angola and Rwanda, the UN forces were brought in at a fairly late stage of the proceedings (Clapman, 1998:9). Moreover, Vogt (1998:7) states that in recent experiences, the OAU has found that even when Africans are prepared to provide the forces for deployment in UN operations in Africa, the Security Council has been reluctant to authorise such missions. One explanation is that some of the Security Council members do not want to commit resources to African operations that may continue for indefinite periods. This was the case in Congo Brazzaville, Sierra Leone and the Comoros. In addition, Bir (1997:25) argues that the current UN structure is not suitable for the proper conducting of intervention operations.

It is furthermore interesting to note that it has been suggested that the intervention operation in the DRC be followed by an international peace-support operation under the auspices of the OAU and the UN. This was jointly proposed by the heads of state from Kenya, Tanzania and Namibia in October 1997 - two months after Zimbabwe, Namibia and Angola had decided to intervene in the DRC. Practically speaking, this implied the orderly disengagement of all troops to allow for neutral peacekeepers as part of a multinational peace-support operation to pave the way for political negotiations (Anon., 1998d:4). Unfortunately, no peace plan has yet been accepted by the belligerents.

What seems to be important is to address potential conflicts or coups before they can take place or can escalate beyond control. This was strikingly articulated by the officer commanding the intervention operation in Lesotho, Col Robbie Hartslief, who suggested that "... this kind of intervention (in Lesotho) be accepted as a new kind of peace-support operation in Africa, because such operations may prevent a massive loss of lives and enormous economic damage". According to Hartslief, everything possible must be done to prevent civil war and this can be achieved only if intervention takes place before an armed conflict can occur. "The problem is that people romanticise peace-support operations. It would seem to me that firstly they want to have an outbreak of civil war, then a cease-fire, then an agreement which is acknowledged by the UN and only then should the peace force move in" (Stofberg, 1998:9). 
The principle behind the preceding viewpoint cannot be disputed. The SecretaryGeneral of the UN, Kofi Annan, has stated himself that peacekeeping (in the broadest sense) can help prevent conflict from breaking out in the first place (Annan, 1998a:3). At the same time, the Secretary-General is also strongly committed to the principle that Africa must rely upon political rather than military responses to problems (Annan, 1998b:29-30) and that conflicts in Africa can only be solved in the framework of compromises, tolerance and peaceful resolution of such conflicts (Valentine, 1998:4).

In the final analysis, it should be borne in mind that peacekeeping is in essence a responsibility of the UN, that it should be endorsed by the world body, and conducted in accordance with the internationalist ethos of the UN Charter. This would imply that any justification for military intervention on the grounds that it is in the interest of peace must proceed from the assumption that it is not contradictory to the UN Charter. To this end, Bir (1997:25) suggests that intervention operations should be led by regional organisations or military organisations, such as NATO, or even a single nation under the political authorisation of the UN. However, this would imply that the formulation of UN mandates should not inhibit swift intervention in internal crises and that regional or sub-regional organisations should clearly provide for guidelines as regards military responses to internal conflicts in the framework of sound objectives. Besides, no organisation may ever prop up any questionable government and the legitimacy of a particular leader may never be something in the eye of the beholder. In addition, no military intervention should ever go beyond the ambit of international law as the international community or regional groupings are obviously not in a position to engage or interfere in any country's domestic affairs in unqualified terms.

\section{Conclusion}

There can be no doubt that the UN is still the principal organ that is vested with the responsibility for the maintenance of international peace and security. But it might also be stated that the UN is a cumbersome participant in the settlement of Africa's fluid and complex conflicts. Moreover, the number of internal wars in this part of the world has challenged all the tools of international conflict management. What is clear from the above is that the international system is unable (or even unwilling in some instances) to provide proper mechanisms for the management or resolution of African conflicts.

In this context, the deterioration of the security situation in Africa has led to a reconsideration of the debate and of the present framework to account for the need for ways and means through which the UN can operate in closer cooperation with continental stakeholders in respect of peace-support operations. What is significant is the fact that the UN now seems prepared to form partnerships with willing regional organisations and alliances in Africa as far as 
conducting peace-support operations are concerned. This relates to the idea of shared responsibility between the UN and continental stakeholders for the effective management of conflicts in Africa. As such, Africa is the first continent where extensive efforts have been made recently between the UN and the OAU with the specific objective of enhancing the management of conflicts in the region. However, many issues remain unclear as regards an ideal arrangement between the UN, the OAU and other role-players, such as the US.

It has also been pointed out that since last year and in parallel with the abovementioned developments, sub-regional organisations in Africa have become directly involved in intervention operations in attempts to intervene before and after the outbreak of civil wars. However, what is of special interest is the fact that the operations in Sierra Leone, the DRC and Lesotho have been conducted without the direct support and authority of the UN. It is also striking that the motives of the different states have not always been consistent and actions have not been undertaken in a circumscribed framework. Consequently, the motives of the interventionists have been called into question while many questions in respect of the modus operandi of these operations have also been raised

In view of the preceding, it would go a long way if the relevant groupings in Africa could develop a set of broad principles for responsibilities to preserve regional security. It is advisable that they should especially work out clear means to respond appropriately and speedily to threats to peace in co-operation with the UN and other stakeholders. It is imperative to develop such principles so as to avoid a haphazard, reactive response and decisions implemented hurriedly in reaction to unforeseen crises - especially as African countries and organisations are in the process of accepting an increasing burden of responsibility for conflict prevention and resolution on the continent. It is likewise of major interest that African governments should not send a message to the world that Africans prefer different methods for dealing collectively with conflict than those accepted by the UN. Hence, it would seem that the legal basis for delegating responsibilities for the maintenance of peace and security in the African context needs to be clarified

Multilateral intervention will always be done on a case-by-case basis, but the judgement itself must be exercised within a circumscribed framework to which all parties have agreed. It also seems to be imperative to cultivate a regional environment in which the use of force remains the last possible means of resolving disputes, especially when action is undertaken on the basis of humanitarian considerations. From a moral and practical viewpoint, an approach that elevates persuasion, conciliation, arbitration and non-violent coercion above the use of force should be favoured. In the final instance, the challenge is to establish an acceptable basis for involvement or intervention in intra-state conflicts that respects the dignity and independence of states without sanctioning 
the misuse of sovereign rights to violate the security of people within a state's borders.

\section{Sources}

ANNAN, K. 1998a. Statement by the United Nations Secretary-General before the special commemorative meeting of the General Assembly honouring 50 years of peacekeeping Internet site http $/ /$ www un .org/Depts/DPKO/pk5060sg.htm.

ANNAN, K. 1998b The causes of conflict and the promotion of durable peace and sustainable development in Aftica: report of the Secretary-General. Internet site http://www un org/Depts/DPKO/pk5060sg. htm.

ANON. 1991. Kampala document for a proposed conference on security, stability, development and cooperation in Africa (CSSDCA). Kampala, May 23.

ANON. 1997 OEA dreig Sierra Leone met geweld. Beeld: 7, February 28

ANON. 1998a. Gloom as Zimbabwe 'backs itself into disaster comer'. Saturday Star. 4, September 19.

ANON. 1998b. OEA stem in tot stigting van Afrika-mag. Beeld 9, February 28.

ANON. 1998c Sierra Leone: Kabbah's comeback. Africa Confidential, 39(4):7-8.

ANON 1998d Vredesmag gevra vir DRK Beeld 4, Okt. 19.

ARNOLD, G. 1997 The OAU and peacekeeping in Africa. New African 33, January

BERMAN, E.G. \& SAMS, K.E 1998. Constructive engagement: Western efforts to develop African peacekeeping. ISS Monograph Series, 23:1-49, December.

BIR, C 1997. Interoperability and intervention operations RUSI Joumal. 22-26, December

BOUTROS-GHALI, B. 1992. An agenda for peace. New York: United Nations.

CLAPMAN, C. 1998. The United Nations and peacekeeping in Africa. Paper presented at a symposium on International Peace and Security: The African Experience. South African Military Academy, Saldanha. 21-23 September 1998.

FABRICIUS, P. 1998a SADC closer to resolution of security impasse. The Star 6, March 4

FABRICIUS, $P$ I998b. SA must face reality in the Congo. The Star. 8, November 6

GIBSON, E. 1998 Eie vredesmagte vir Afrika 'onontbeerlik' Beeld. 11, Maart 4.

HAYSOM, F 1998. Defending regional democracy. The Star, 6, October 14

HENK, D. 1995 Peace operations: views from southern and eastern Africa. U.S. Army Peacekeeping Institute Occasional Paper, US Army War College.

HENK, D \& METZ, S. 1997 The United States and the transformation of African security the African Crisis Response Initiative and beyond Strategic Studies Institute Report. US Army War College December 5

HOUGH, M. 1998 Collective security and its variants: a conceptual analysis with specific reference to SADC and Ecowas. Strategic Review for Southern Africa, XX(2) 23-43, December

INSTITUTE OF PUBLIC POLICY (Georg Mason University) 1998 Discussion on the Aftican Crisis Response Force. Internet site http:/ralph gmu.edu/cfpa/peace/peace.html

JAMERSON, J. 1998. A United States contribution to capacity-building: the African Crisis Response Initiative. (In Malan, M., ed. Resolute partners: building peacekeeping capacity in southern Africa ISSMonograph Series, 21:43-49, February.)

LOTTER, F. 1998 'n Week in die wêreld. Beeld 9, October 24.

MALAN, M 1997. US response to African crises: an overview and preliminary analysis of the ACRI. ISS Papers, 24:1-7

MALAN, M 1998a. Peacekeeping in Africa: trends and responses. Paper presented at a seminar on "Building African Peacekeeping Capacity". Institute for Security Studies, Midrand. 20 May 1998.

McFARLANE, F. \& MALAN, M. 1998. Crisis and response in the Central African Republic: a new trend in African peacekeeping. African Security Review, 7(2):48-58 
MDHLELA, J 1998. UN steps in to deal with Congo crisis. Sowetan 1, September 3

NHARA, W. 1995 The OAU and the potential role of regional and sub-regional organisations (In Cilliers, J \& Mills, G., eds. Peacekeeping in Africa Johannesburg : Institute for Defence Policy and South African Institute of International Affairs. p 99108 , February.)

NHARA, W. 1998. Conflict management and peace operations: the role of the Organisation of African Unity and subregional organisations. (In Malan, M., ed Resolute partners building peacekeeping capacity in southern Africa. ISS Monograph Series, 21:32-42.)

OLONISAKIN, F 1997. African 'homemade' peacekeeping initiatives Armed Forces \& Society, 23(3):349-372

ORGANISATION FOR AFRICAN UNITY (Central Organ). Not dated OAU's position towards the various initiatives on conflict management: enhancing OAU's capacity in preventive diplomacy, conflict resolution and peacekeeping, Min/3(iv)

ORGANISATION FOR AFRICAN UNITY 1993. Declaration of the Assembly of Heads of State and Government on the establishment within the OAU of a Mechanism for Conflict Prevention, Management and Resolution Cairo, June 30.

SAPA-AFP \& REUTERS. 1998. At least 50 die as war erupts in Sierra Leone The Star:4, February 12.

SHELTON, H. 1987 Return to Africa special operations forces support new initiative in a familiar place Armed Forces Joumal. 80-82, October.

SOUTHERN AFRICAN DEVELOPMENT COMMUNITY. 1999. Exercise Blue Crane South Africa 7-30 April 1999: info booklet for military attachés. Published on 30 March 1999.

STEYN, P 1997. South Africa and peace-support operations: limitations, options and challenges. Paper presented at a conference on Contemporary Peace-support Operations University of South Africa, Pretoria. 5 November 1997

STOFBERG, A. 1998 'SA moet mag nou steun'. Beeld. 9, October 3.

TSIE, B 1998. Regional security in southern Africa: whither the SADC Organ for Politics, Defence and Security. Global Dialogue, 3(3):8-10.

UNITED NATIONS. 1945. Charter of the United Nations. San Francisco.

UNITED NATIONS (Department of Political Affairs) 1998a. Preventive action and peacemaking. Internet site http://www un.org/Depts/dpa/docs/peacemak.htm.

UNITED NATIONS (Department of Public Information). 1998b. UN peace-keeping: some questions and answers. Internet site http://www un.org/Depts/dpko/faq htm

VAN AARDT, M. 1997. The emerging security framework in southern Africa: regime or community. Strategic Review for Southern Africa, XIX(1):1-30, May.

VALENTINE, S. 1998. Annan pleit by Afrika-leiers om militêre oplossings te verwerp Beeld. 4, October 7.

VOGT, $M$ 1998. Cooperation between the United Nations and the OAU in the management of African conflicts Paper presented at a symposium on "International Peace and Security: The African Experience" SA Military Academy, Saldanha. 21-23 September 1998

WHITELAW, K 1997 A mission for Africa: the West makes peacekeeping a do-it-yourself project US News and World Report, September 29.

WILLIAMS, R 1995. Peace operations and the South Aftican armed forces. Strategic Review for Southern Africa, XVII(2):87-107, May

WILLIAMS, R 1997 Don't hold the African Crisis Response Force hostage to unrealistic demands. ISS Papers, 20:1-3. 